\title{
Pelatihan Pelaksanaan K3 Terhadap Risiko Kebakaran Di Madrasah Ibtidaiyah Al Huda
}

\author{
Pratiwi Setyaning Putri $^{1}$; Dicki Dian Purnama ${ }^{2}$; Budi Wicaksono ${ }^{3}$ \\ 1, 2, 3 Institut Teknologi PLN \\ ${ }^{1}$ pratiwi@itpln.ac.id
}

\begin{abstract}
Indonesia is the most vulnerable country to disasters in the world based on data released by the United Nations Agency for the International Strategy for Disaster Risk Reduction (UN-ISDR) ${ }^{[1]}$. This will certainly have an impact on the number of fatalities if there is no understanding and good handling of the parties involved. Alert and alert attitudes are still very minimal and are often not taught in formal teaching and learning activities. In addition to human resources, disaster risk reduction can also be pursued by providing adequate $K 3$ facilities in each building. Madrasah Ibtidaiyah Al Huda which is on Jalan Al Huda Rawasapi RT 02/09 Kelurahan Jatimulya - Tambun Selatan Bekasi District has a moderate earthquake risk. In addition, the location of schools that are not on the main road and access roads to locations that are relatively difficult to pass by fire trucks make it vulnerable in the event of a fire disaster. The solution offered is education of OHS implementation of disasters and the provision of facilities and infrastructure to deal with these disasters. The expected output targets are one PKM article published through an ISSN journal, one ISBN proceeding article from a national seminar organized by STT-PLN, and publication in print I electronic media.
\end{abstract}

Keywords: disaster mitigation, fire, $\mathrm{OHS}$

\begin{abstract}
ABSTRAK
Indonesia menjadi negara yang paling rawan terhadap bencana di dunia berdasar data yang dikeluarkan oleh Badan Perserikatan Bangsa-Bangsa untuk Strategi Internasional Pengurangan Resiko Bencana $(U N-I S D R)^{[I]}$. Hal tersebut tentu akan berdampak terhadap banyaknya korban jiwa yang jatuh jika tidak ada pemahaman dan penanganan yang baik dari pihak-pihak terkait. Sikap waspada dan siaga masihlah sangat minim dan seringkali tidak diajarkan dalam kegiatan belajar mengajar formil. Selain pihak SDM pengurangan resiko bencana dapat pula diupayakan dengan penyediaan fasilitas K3 yang memadai di tiap bangunan. Madrasah Ibtidaiyah Al Huda yang berada di Jalan Al Huda Rawasapi RT 02/09 Kelurahan Jatimulya - Tambun Selatan Kabupaten Bekasi memiliki resiko gempa sedang. Selain itu letak sekolah yang tidak berada di jalan utama dan jalan akses ke lokasi yang relatif sulit untuk dilalui oleh mobil pemadam kebakaran menjadikannya rentan jika terjadi bencana kebakaran. Solusi yang ditawarkan yaitu dengan edukasi pelaksanaan K3 terhadap bencana serta penyediaan sarana dan prasarana untuk menghadapi bencana-bencana tersebut. Target luaran yang diharapkan adalah adanya satu artikel PKM yang dipublikasikan melalui jurnal ber ISSN, satu artikel prosiding ber ISBN dari seminar nasional yang diselenggarakan STT-PLN, serta publikasi pada media cetak / elektronik.
\end{abstract}

Kata Kunci: mitigasi bencana, kebakaran, K3 


\section{PENDAHULUAN}

Indonesia merupakan daerah rawan bencana dan bencana dapat terjadi disebabkan oleh alam maupun ulah manusia. Hal ini terbukti telah terjadi berbagai bencana di beberapa daerah seperti gempa bumi, tsunami, banjir dan banjir bandang, tanah longsor, letusan gunung api, kebakaran, kebakaran hutan dan lahan, angin putting beliung, kegagalan teknologi, kecelakaan transportasi serta konflik sosial. Akibat dari bencana-bencana dimaksud berdampak pada rusaknya lingkungan, permukiman penduduk, sarana prasarana vital dan membawa kerugian harta benda dan penderitaan serta korban jiwa manusia ${ }^{[2]}$.

Bencana adalah peristiwa atau rangkaian peristiwa yang mengancam dan mengganggu kehidupan dan penghidupan masyarakat yang disebabkan, baik oleh faktor alam dan/atau faktor nonalam maupun faktor manusia sehingga mengakibatkan timbulnya korban jiwa manusia, kerusakan lingkungan, kerugian harta benda, dan dampak psikologis. Sedangkan mitigasi bencana adalah serangkaian upaya untuk mengurangi risiko bencana, baik melalui pembanguna fisik maupun penyadaran dan peningkatan kemampuan menghadapi ancaman ${ }^{[3]}$.

Dalam UU No. 24 tahun 2007, mitigasi didefinisikan sebagai serangkaian upaya untuk mengurangi risiko bencana, baik melalui pembangunan fisik maupun penyadaran dan peningkatan kemampuan menghadapi ancaman bencana. Mitigasi bencana merupakan suatu aktivitas yang berperan sebagai tindakan pengurangan dampak bencana, atau usaha-usaha yang dilakukan untuk mengurangi jumlah korban dan kerugian ketika bencana terjadi, baik korban jiwa maupun harta ${ }^{[4]}$.

Madrasah Ibtidaiyah Al Huda berada di Jalan Al Huda Rawasapi RT 02/09 Kelurahan Jatimulya - Tambun Selatan Kabupaten Bekasi. Berada sekitar $200 \mathrm{~m}$ dari jalan utama dan dikelilingi oleh pemukiman penduduk. Fasilitas keamanan dan kesehatan yang ada saat ini berupa alat P3K milik Sekolah. Belum tampak ada rambu evakuasi dan alat K3 lain yang mendukung kondisi sekolah dalam keadaan darurat bencana.

\section{METODE PELAKSANAAN}

Kegiatan PKM Penerapan dan Edukasi Pelaksanaan K3 Terhadap Risiko Kebakaran di Madrasah Ibtidaiyah Al Huda mengikuti acuan diagram alir berikut ini :

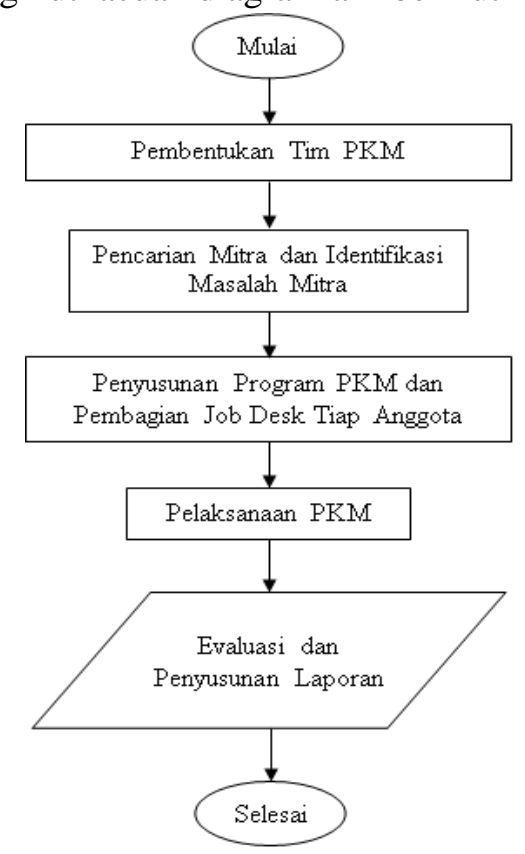

Gambar 1. Diagram alir kegiatan PKM 
Tahapan PKM dibagi menjadi beberapa tahapan :

1. Tahapan awal merupakan pembuatan tim PKM yang beranggotakan 3 orang.

2. Mencari mitra sekaligus permasalahan yang dihadapi oleh mitra tersebut. Kemudian mencari alternatif solusi yang bisa diaplikasikan atau dilakukan

\section{HASIL DAN PEMBAHASAN}

Istilah Sekolah Aman, Sekolah Aman Bencana dan Sekolah Tangguh digunakan untuk rangkaian kegiatan di sekolah yang berkesinambungan dan di secara holistik (struktural maupun non struktural) melalui:

a) Pemenuhan / pembelian fasilitas keselamatan dan pengurangan risiko bencana,

b) Membangun dan menjalankan manajemen sekolah aman, dan

c) Penyebarluasan informasi pengurangan risiko bencana dan tindakan keselamatan.

Ketiga upaya tersebut bertujuan agar warga belajar mendapatkan perlindungan setiap saat dan disaat bencana terjadi serta memiliki kemampuan mengembalikan fungsi belajar dan mengajar setelah bencana terjadi ${ }^{[5]}$.

Sebelum diadakan kegiatan penerapan dan edukasi pelaksanaan K3 terhadap risiko kebakaran di Madrasah Ibtidaiyah Al Huda, murid dan guru belum memahami secara menyeluruh mengenai tindakan K3 yang dapat dilakukan terhadap risiko kebakaran. Setelah dilakukan edukasi diketahui bahwa pada efek kognitif, peserta penyuluhan dalam hal ini murid dan guru mendapat pengetahuan baru dengan memahami pesan/informasi yang diberikan oleh penyuluh untuk Madrasah Ibtidaiyah Al Huda. Efek yang ditimbulkan hingga ke konatif dimana perserta mulai bertindak sesuai dengan apa yang telah dipahami dan diketahui mengenai materi yang telah disampaikan.

Tabel 1. Hasil Nilai Pre Test dan Post Test

\begin{tabular}{|c|c|c|c|}
\hline \multicolumn{2}{|c|}{ HASIL NILAI PRE TEST } & \multicolumn{2}{c|}{ HASIL NILAI POST TEST } \\
\hline Nilai & $\begin{array}{c}\text { Jumlah Siswa } \\
\text { (orang) }\end{array}$ & Nilai & $\begin{array}{c}\text { Jumlah Siswa } \\
\text { (orang) }\end{array}$ \\
\hline 1 & 3 & 1 & 0 \\
\hline 2 & 15 & 2 & 0 \\
\hline 3 & 8 & 3 & 2 \\
\hline 4 & 7 & 4 & 3 \\
\hline 5 & 9 & 5 & 7 \\
\hline 6 & 5 & 6 & 10 \\
\hline 7 & 2 & 8 & 14 \\
\hline 8 & 0 & 9 & 6 \\
\hline 9 & 1 & 10 & Nilai Rata-Rata Post Test $=\mathbf{7 , 5 8}$ \\
\hline 10 & 0 & \multicolumn{2}{c|}{} \\
\hline \multicolumn{2}{|c|}{ Nilai Rata-Rata Pre Test $\mathbf{3 , 6 6}$} &
\end{tabular}

Edukasi kegiatan praktek penggunaan alat pemadam kebakaran dilakukan oleh Tim Damkar Kabupaten Bekasi dengan didampingi oleh Tim PKM IT PLN. Jumlah personel damkar yang diterjunkan berjumlah 3 orang dengan Alat Pelindung Diri (APD) lengkap. Pada kegiatan praktek ini dilakukan prosedur pemadaman dengan alat sederhana yakni dengan karung / kain basah serta menggunakan Alat Pemadam Api Ringan (APAR). APAR yang digunakan merupakan type $\mathrm{C}$ yang berbentuk bubuk (powder). Sebelum memulai praktek langsung dilakukan pengarahan oleh tim 
DAMKAR mengenai alat dan bahan yang bisa digunakan untuk pemadaman api serta type-type APAR yang ada di pasaran.

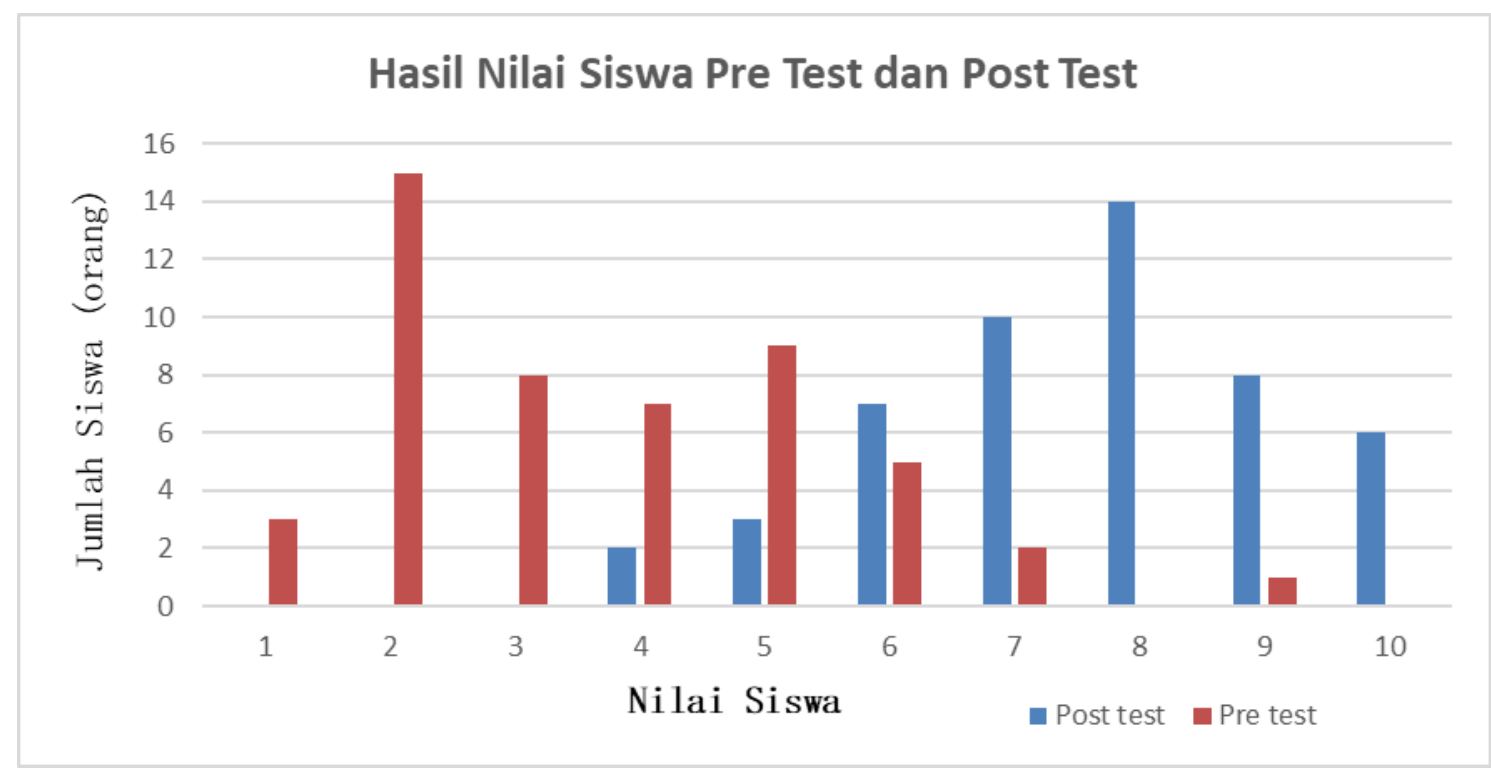

Gambar 2. Hasil Nilai Siswa Pre Test dan Post Test

Selama kegiatan berlangsung, terlihat antusias peserta yang cukup besar. Hal ini tampak dari semangat para peserta selama sesi pemaparan materi, ikut serta dalam praktek, serta adanya timbal balik dari peserta pada sesi tanya jawab.

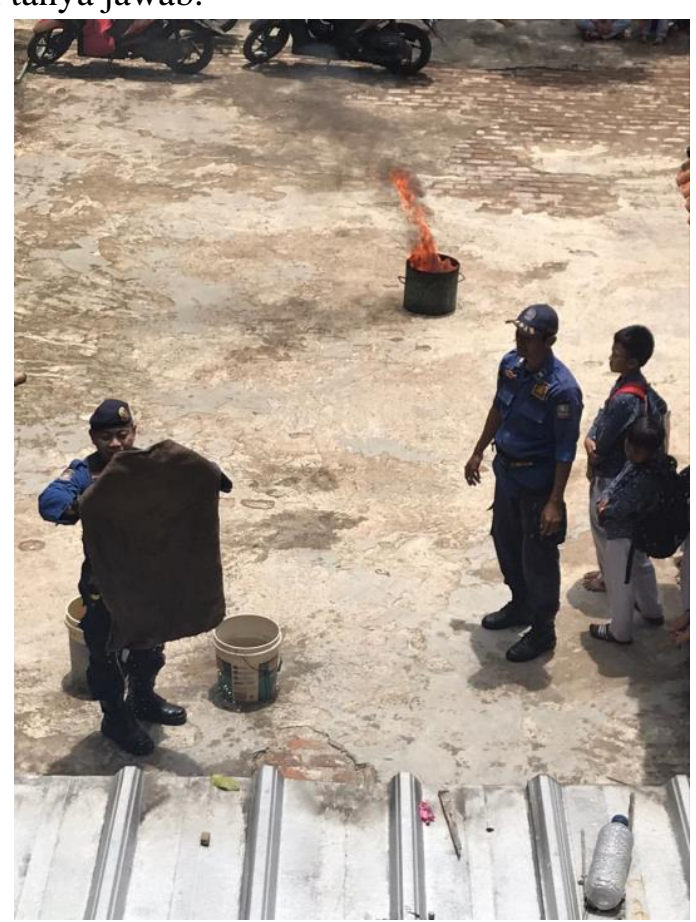

Gambar 3. Pemaparan Prosedur Pemadaman Oleh Tim DAMKAR 

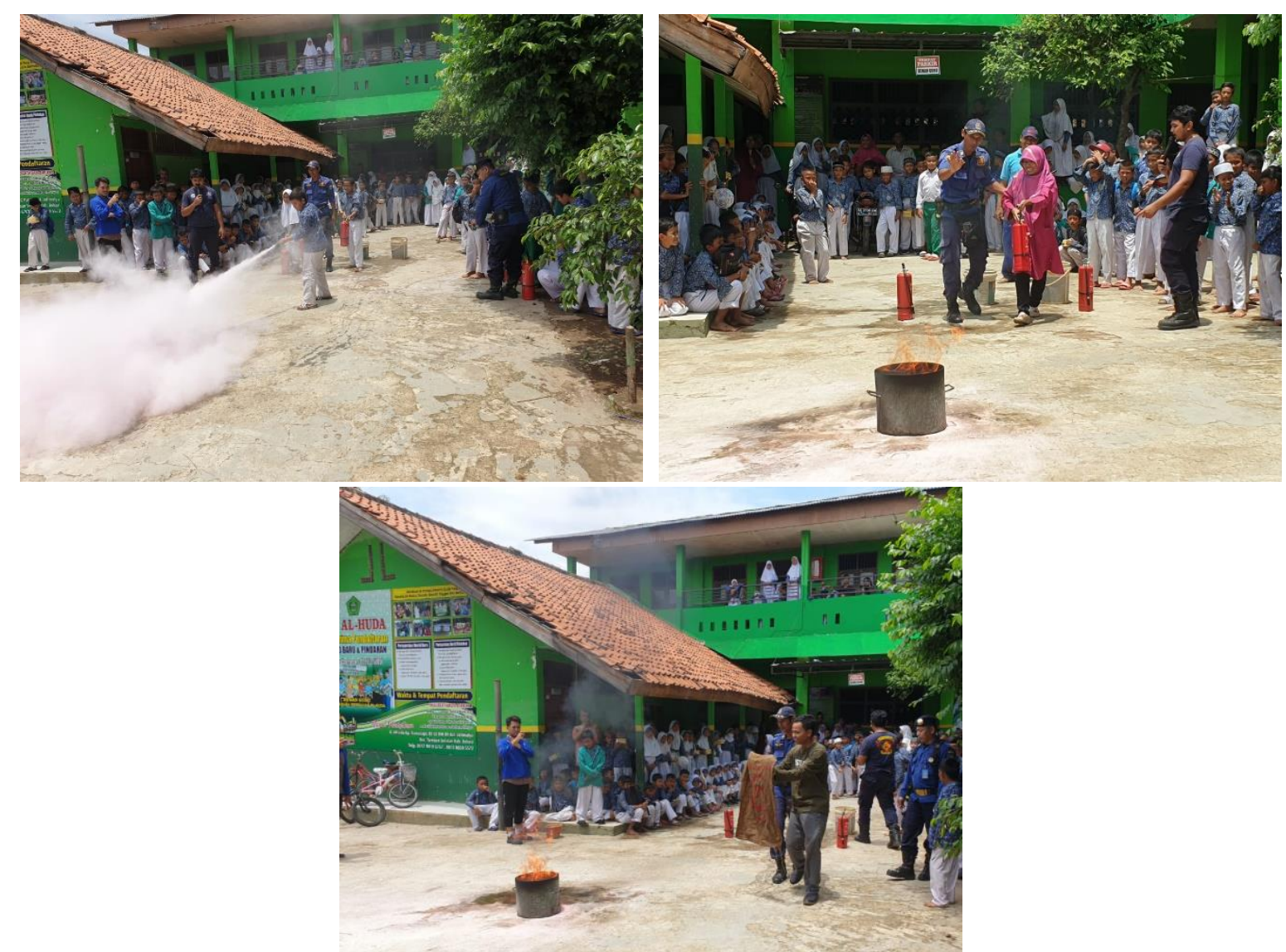

Gambar 4. Praktek Pemadaman Api oleh Murid, Guru dan Tim PKM

Untuk proses pemadaman dengan karung / kain basah hanya dilakukan oleh guru dan tim PKM mengingat bahaya yang cukup tinggi jika dilakukan oleh siswa yang masih berada pada level Madrasah Ibtidaiyah. Para siswa hanya mengikuti pelatihan dengan APAR.

Setelah melakukan edukasi dan praktek mengenai penerapan K3 terhadap risiko kebakaran di Madrasah Ibtidaiyah Al Huda, Tim PKM IT-PLN melakukan pemasangan fasilitas keselamatan terhadap risiko kebakaran. Fasilitas tersebut antara lain:

1. Pemasangan poster edukasi pada setiap kelas dan ruang guru

2. Pemasangan box hydrant dan hydrant yang tersebar pada setiap $5 \mathrm{~m}$ selasar

3. Pemasangan titik kumpul

4. Pemasangan sticker petunjuk arah untuk menuju ke titik kumpul

Kendala yang dihadapi selama kegiatan penerapan dan edukasi adalah terkait dengan waktu terselenggaranya acara. Hal ini dikarenakan target edukasi adalah Madrasah Ibtidaiyah Al Huda yang telah memiliki kalender akademik dan kegiatan masing-masing, maka waktu pelaksanaan edukasi cukup sulit disesuaikan antara Madrasah Ibtidaiyah Al Huda dan IT PLN.

Secara umum, kegiatan edukasi yang dilakukan oleh Tim PKM IT-PLN ini dapat terselenggara dengan baik dan lancar. Seluruh jajaran Madrasah Ibtidaiyah Al Huda setempat sangat mendukung penuh kegiatan edukasi ini. Beberapa guru juga banyak membantu Tim PKM IT PLN dalam mempersiapkan kegiatan. Selain itu, semua peserta juga berperan aktif dalam diskusi selama kegiatan berlangsung. 

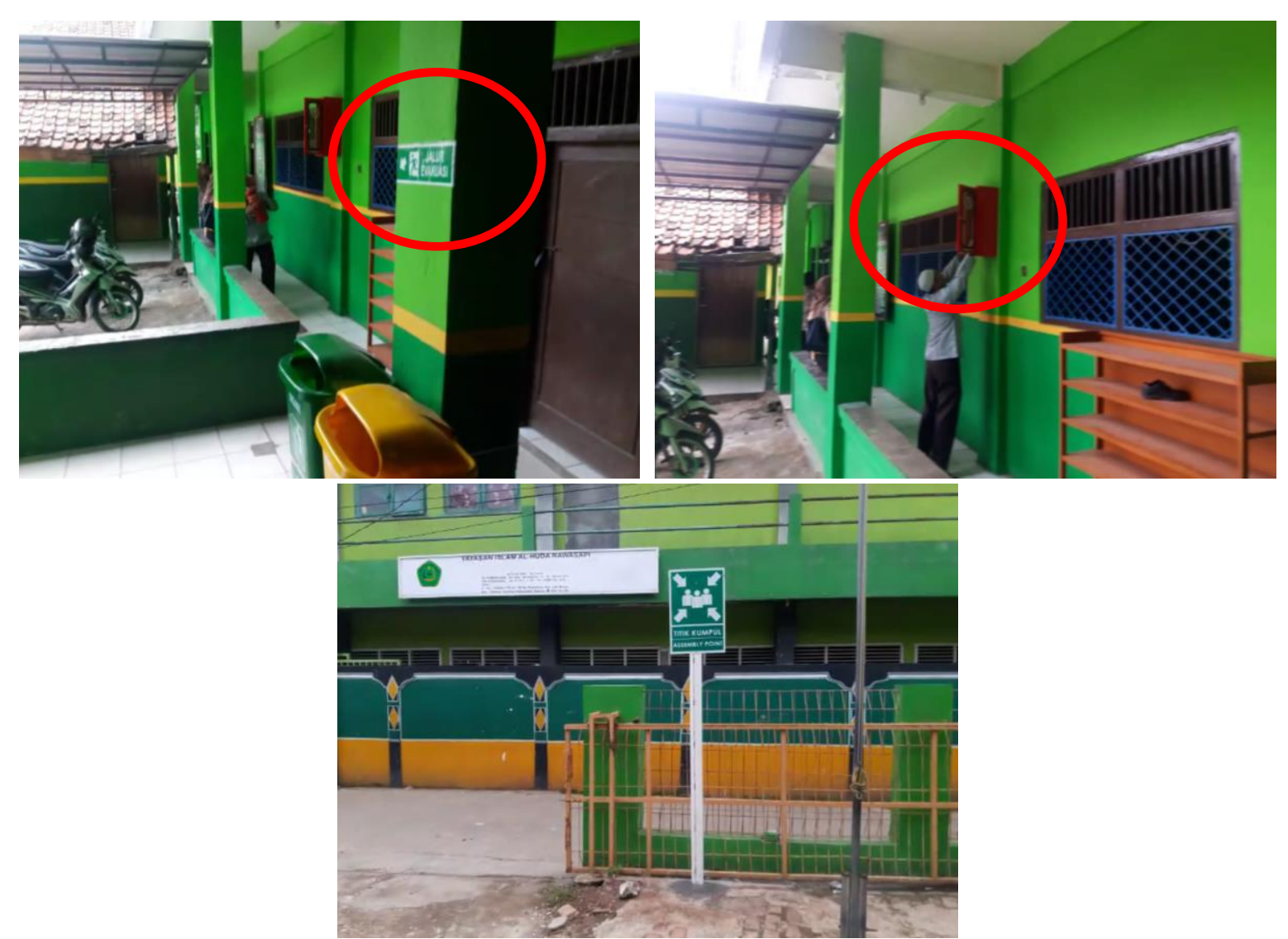

Gambar 5. Fasilitas Keselamatan Bencana Kebakaran

\section{KESIMPULAN}

Setelah kegiatan edukasi terlaksana, beberapa hal yang telah dicapai adalah:

1. Peserta memahami penyebab risiko kebakaran

2. Peserta memahami dampak risiko kebakaran.

3. Peserta memahami tindakan preventif dan tindakan korektif risiko kebakaran.

4. Peserta memahami fungsi dan cara penggunaan alat pemadam kebakaran.

5. Peserta memahami penerapan K3 secara keseluruhan terhadap risiko kebakaran di sekolah.

\section{SARAN}

Berikut ini adalah beberapa saran yang dapat dianjurkan oleh penulis:

1. Diharapkan kegiatan serupa dapat diadakan tidak hanya di lingkungan sekitar kampus ITPLN, mengingat pentingnya pengetahuan tentang K3 terhadap risiko keakaran sebagai upaya untuk menjaga keselamatan seluruh murid dan guru di sekolah.

2. Adanya kegiatan lanjutan berupa pembahasan mengenai $\mathrm{K} 3$ terhadap risiko lainnya yang dapat terjadi di sekolah

\section{UCAPAN TERIMAKASIH}

Penulis mengucapkan terima kasih kepada Madrasah Ibtidaiyah Al Huda dan IT PLN yang telah memberi dukungan yang membantu pelaksanaan PKM dan atau penulisan artikel. 


\section{DAFTAR PUSTAKA}

[1] BBC News, 2011, Indonesia Negara Rawan Bencana, https://www.bbc.com/indonesia/berita_indonesia/2011/08/110810_indonesia_tsunami diakses: 10 Februari 2020.

[2] PP Kepala Badan Nasional Penanggulangan Bencana, 2009, Pedoman Standarisasi Peralatan Penaggulangan Bencana, Jakarta.

[3] Badan Nasional Penanggulangan Bencana, 2008, Peraturan Kepala Badan Nasional Penanggulangan Bencana nomor 4 tahun 2008 tentang Pedoman Penyusunan Rencana Penanggulangan Bencana, Jakarta.

[4] Undang - Undang Nomor 24 Tahun 2007 Tentang Penanggulangan Bencana.

[5] Lasmana, Ujang Dede., 2015. Sudah Amankah Sekolah Anak Kita?, Jakarta 